\title{
THE EFFECT OF HEALTH EDUCATION ON PREGNANT WOMEN'S KNOWLEDGE LEVEL ABOUT COVID-19 IN MAIN CLINIC CIDENG MEDICAL CENTER REGENCY OF CIREBON IN 2020
}

\author{
Fadillah Mawaddah, Dyah Widiyastuti \\ Poltekkes Kemenkes Tasikmalaya \\ fadillahmwd@gmail.com
}

\begin{abstract}
Health education is an effort to convey the health message that is expected that people, groups, or individuals can gain knowledge about better health so that it can affect behavior. Video media is a health education tool used to facilitate the reception of health messages that rely on the senses of vision and hearing. Pregnant women are at considerable risk of being infected with COVID-19. There is still a low knowledge of pregnant women about COVID-19 at Cideng Medical Center Main Clinic by $40 \%$. The purpose of this study is to analyze the differences in pregnant women's knowledge about COVID-19 before and after the provision of health education about COVID-19 at the Main Clinic of Cideng Medical Center CirebonDistrict in 2020. Research design using a quasi-experimental design with one group design pre test-post test without control design. The sampling technique used is accidental sampling. The population in this study was pregnant women, with a sample of 30 respondents.The results of the analysis with the Wilcoxon T-Test test in pregnant women before and after obtained a p-value of 0.000 from the results of the study obtained a value of $p<0.05$ so that the hypothesis is accepted. The average increase in the knowledge level score of pregnant women between before and after being given health education was 2.13. There is an influence of health education on the level of knowledge of pregnant women about COVID-19 at the Main Clinic of Cideng Medical Center Cirebon Regency in 2020.
\end{abstract}

Keywords: COVID-19; Pregnant Women; Video Media; Health Education; knowledge

\section{Introduction}

China reported on December 2019 an unknown case of pneumonia. Initially, the case was reported in
Wuhan, Hubei Province. In three days, the number of patients with such cases numbered 44 people and continues to grow to this day numbered thousands of 
DOI: $\underline{10.34305 / g e m i c . v 1 i 1.314}$

cases. Coronavirus disease 2019 (COVID-19) is a disease that is spreading almost all over the world today, caused by severe acute respiratory syndrome coronavirus- 2 (SARS-CoV-2). Originally named coronavirus (2019-nCoV) then on February 11, 2020, the World Health Organization (WHO) named the new virus Severe Acute Respiratory Syndrome coronavirus-2 (SARS-CoV2) and named the disease coronavirus disease 2019 (COVID-19) (Simanjuntak 2020).

As of January 10, 2021, data from WHO obtained 88,383,771 confirmed cases spread across 223 countries with $1,919,126$ deaths (who.int). Data in Indonesia as of January 10, 2021, shows 828,026 confirmed cases spread across 34 provinces with 22,129 deaths. Indonesia is the 65th country to confirm COVID19 (Pusicov Indonesia, 2021). Data in West Java until January 10, 2021, shows 97,570 confirmed cases spread across 27 cities/districts in West Java with the number of deaths 1,140 cases (pikobar.jabarprov.go.id). Meanwhile, data in Cirebon until January 10, 2021, showed 560 cases and 72 deaths (Pusicov Cirebon Regency, 2021).

Common signs and symptoms of COVID-19 infection can be nonsymptomatic, mild, moderate, to severe symptoms. The main clinical symptoms that appear are fever (temperature > $38^{\circ} \mathrm{C}$ ), cough, and difficulty breathing. The average incubation period is 5-6 days with the longest incubation period being 14 days. In severe cases of COVID-19, it can cause pneumonia, acute respiratory syndrome, kidney failure, and even death. Until now, there is still no evidence that pregnant women are more at risk of COVID-19 than the general population. However, due to changes in the body and immunity, it is believed that pregnant women have a higher risk for severe diseases, morbidity, and mortality compared to the general population if exposed to COVID-19 infection (WHO, 2020).

On January 30, 2020 WHO has designated COVID-19 as a Public Health Emergency that is troubling the 
world, then on March 11, 2020 COVID19 was designated as a pandemic, which means COVID-19 that has spread to several countries or continents, and infected many people. It is also inseparable in the pregnant population. Therefore, pregnant women should be aware of the risk of contracting COVID-19 (Simanjuntak, 2020).

The spread of the COVID-19 pandemic in Indonesiahas increased every day and by the end of December 2020 almost 10,000,000 positively confirmed cases have been established. One vulnerable group is pregnant women. Quoted from several sources that more and more pregnant women in Indonesia are positive of COVID-19. Cases of pregnant women in Indonesia infected with COVID-19 include on April 8, 2020 in Bukittinggi, West Sumatra, 1 8-month pregnant woman died with her baby (liputan6.com). On April 24, 2020 in Bali, a 7-month pregnant woman died in the womb (bali.tribunnews.com). On June 20, 2020 in Batu City, Surabaya,
20 pregnant women were infected with Corona virus. The 50th patient is an 8month pregnant woman who died with her baby (madura.tribunnews.com).

On September 10, 2020, yogyakarta's COVID-19 Handling Task Force said there were 13 cases of pregnant women being infected. On September 3, 2020, the Surabaya City Government obtained data on 123 COVID 19 positive pregnant women but as many as 90 pregnant women have recovered and as many as 33 people are still undergoing treatment. On September 1, 2020, positive cases of COVID-19 in Gresik are increasing. There are already 20 pregnant women who are COVID-19 positive. On September 3, 2020, there were 3 pregnant women who were positive for

COVID19 in Lampung (popmama.com).

To date, knowledge of COVID19 infections in relation to pregnancy and fetus is still limited and there have been no specific recommendations for the treatment of pregnant women with 
COVID-19. Fetal side effects in the form of preterm childbirth are also reported in pregnant women with COVID-19 infection (WHO, 2020).

Some research shows that pregnant women have a considerable risk of being infected with COVID-19, including mild symptoms. The Center for Desease Control and Prevention (CDC) notes that pregnant women are more susceptible to all types of respiratory infections, such as flu. This is partly because pregnancy changes the immune system in addition to affecting the lungs and heart. One of the researches on this subject was conducted by the Priority Study of the University of California San Francisco. The study involved about 30 pregnant women in China who were exposed to COVID-19. Another study published by the American Journal of Obstetrics \&Gynecology in March 2020 suggests that there is no concrete evidence to suggest that pregnant women are more susceptible to COVID19 than others (tirto.id).
Health education is an activity or effort to convey a health message. The existence of this message is expected that the community, group or individual can gain knowledge about better health so that it can affect behavior (Notoatmodjo, 2010). While the media is a health education tool used to facilitate the reception of health messages for the community (Fitriani, Sinta, 2011). Health education cannot be released from the media because through the media the messages delivered can be more interesting and easy to understand, so that the target can study the message so that until it decides to adopt it into positive behavior (Notoatmodjo, 2010b).

Basically there are three kinds of aids that support health education in gaining knowledge, namely: visual aids, hearing aid sand hearing aids (Audio Visual Aids) (Fitriani, Sinta, 2011).

Video media is a medium that uses the sense of hearing and vision (audio visual aids)to help convey health messages. Video media falls into the category of audio-visual teaching 
materials or listening materials. The advantages of video media is that it is well known that the public includes five senses, easier to understand, can be played over and over again, more interesting because there are sounds and moving images (Notoatmodjo, 2010a).

The media or tools are prepared based on the principle that the more five senses used to receive something, the more and more clearly the understanding or knowledge obtained (Fitriani, Sinta, 2011). Knowledge is the result of knowing, and this happens after people sense a particular object. Sensing of a human sense of five senses, namely the sense of vision, smell, taste and raba (Notoatmodjo 2010a). Good knowledge about COVID-19 is expected that mothers will have a good attitude to protect themselves by implementing a clean lifestyle, even later after the COVID-19 case has passed. As well as equipping yourself with the latest knowledge and information related to COVID-19 that is accurate and reliable (Santi, Dwi, 2020).
Based on research conducted by (Kurniawati, 2012) on Differences in Media Leaflets and Videos On Maternal Knowledge On How to Overcome Complaints During Pregnancy shows the results that there is a difference between media leaflets and videos to knowledge. The mean value in the video group (9.40) is higher than the leaflet group (5.80), so it can be concluded that the video media gives better results. Other research shows that there is an increase in knowledge and attitude after being given health education with audiovisual media seen at a mean knowledge value of $15.8 \pm$ 0.34 and an attitude mean value of 12.8 \pm 0.37 with a $\mathrm{p}$ value of $0.000<a 0.05$ (Zakaria, F, 2017).

Based on the results of studies that have been conducted at the Main Clinic Cideng Medical Center Cirebon Regency, author conducted a brief interview on 10 pregnant women obtained the results that 4 pregnant women have good knowledge about COVID-19 and 6 pregnant women have less knowledge 
DOI: $\underline{10.34305 / g e m i c . v 1 i 1.314}$

about COVID-19. This shows that pregnant women lack knowledge about COVID-19 at Cideng Medical Center Main Clinic. Because of the importance of knowledge about COVID-19 to be known by pregnant women, therefore by knowing COVID-19 all risks that will occur can anticipate well.

\section{Method}

This research is quantitative analytical research, because the data of the research results in the form of figures that can be analyzed based on statistical procedures (Notoatmodjo, 2012). The research design used is quasi experimental design, which is research that gives treatment to objects that can control variables and expressly state the existence of causal relationships. The research design used is one group pretest-posttest without control design, which is experimental research conducted in one group that is selected randomly and not conducted stability tests and clarity of the condition of the group before being treated (Notoatmodjo, 2012).

The design of this study, it begins with the filling of identity and informed consent. Then the initial test (pretest) aims to assess pregnant women's knowledge about COVID19 through google form spread through whatsapp. Furthermore, health education treatment regarding COVID19 with online video media (through whatsapp application) and ended with a final test (posttest). In this study to find out the effect of health education with video media on the level of knowledge of pregnant women about COVID-19.

\section{Results}

Characteristics

The characteristics of respondents in this study include age and education. Here is a table of frequency distribution characteristics of respondents to this study:

Table 1. Frequency Distribution of Respondent Characteristics

\begin{tabular}{ccc}
\hline Characteristic & Frequency $(n)$ & Percentage $(\%)$ \\
\hline
\end{tabular}


DOI: $\underline{10.34305 / g e m i c . v 1 i 1.314}$

\begin{tabular}{lcc}
\hline Age & & \\
\hline 19-25 Years Old & 13 & 43,3 \\
\hline $26-32$ Years Old & 9 & 30 \\
\hline $33-40$ Years Old & 8 & 26,7 \\
\hline Last Education & 3 & 10 \\
\hline Primary School & 18 & 60 \\
\hline High School/Vocational School & 9 & 30 \\
\hline PT/Academy & 30 & 100 \\
\hline Number of Pregnant Women & &
\end{tabular}

Based on table 1, it can be concluded that most of the 13 respondents were between 19-25 years old $(43.3 \%)$, most of the last high school education as many as 18 respondents $(60 \%)$ and the number of pregnant women as many as 30 respondents $(100 \%)$.

\section{Univariate Analysis}

Table 2. Distribution of Pre-test and Post-test Knowledge of Respondents

\begin{tabular}{lllllllll}
\hline Knowledge & N & Min Max & Mean & Sd & Median & 95\% CI & $\begin{array}{c}\text { Total } \\
\text { Value }\end{array}$ \\
\hline Pretest & 30 & 11 & 21 & 18,10 & 1,749 & 18,00 & $17,45-18,75$ & 21 \\
Posttest & 30 & 19 & 21 & 20,27 & 0,785 & 20,00 & $19,97-20,56$ & 21 \\
\hline
\end{tabular}

Based on table 4, it can be concluded that the average knowledge of pregnant women about COVID-19 before being given health education is 18.10. The lowest is 11 and the highest is 21 . The median value is 18.00 with $a$ standard deviation of 1,749 . The result of $95 \%$ confidence interval $(\mathrm{CI})$ can be concluded that $95 \%$ of pregnant women's concern about COVID-19 between 17.45 to 18.75 and the average after being given health education is 20.27. The lowest is 19 and the highest is 21 . The median value is 20.00 with $a$ standard deviation of 0.785 . The result of $95 \%$ confidence interval $(\mathrm{CI})$ can be concluded that $95 \%$ of pregnant women's concern about COVID-19 between 19.97 to 20.56. There was an increase in the average knowledge level score of 2.13 .

\section{Bivariate Analysis}

Bivariate analysis was conducted to determine the influence of independent variables (health education through video media) with dependent 


\section{eMICH $D_{x}$}

variables (pregnant women's knowledge of COVID-19) indicated by a $p$ value of $<0.05$. Furthermore, to find out if normal distributed research data on knowledge level data before and after being given health education $1^{\text {st }}$ INTERNATIONAL SEMINAR OF GENDER, MATERNAL, EQUITY AND CHILD HEALTH

\section{DOI: 10.34305/gemic.v1i1.314}

interventions through video media, the Shapiro Wilk test was used.

\section{a. Normality Test}

The data normality test was conducted using Shapiro Wilk using computer software.

Table 3. Normality Test Results of Knowledge Level Pregnant Women about COVID-19

\begin{tabular}{ccccccc}
\hline & \multicolumn{2}{c}{ A Kolmogorov-Smirnov } & \multicolumn{3}{c}{ Shapiro-Wilk } \\
\cline { 2 - 7 } & Statistics & Df & Sig. & Statistics & Df & Sig. \\
\hline Difference & 0,218 & 30 & 0,001 & 0,804 & 30 & 0,000 \\
Pretest & 0,311 & 30 & 0,000 & 0,726 & 30 & 0,000 \\
Posttest & 0,292 & 30 & 0,000 & 0,773 & 30 & 0,000 \\
\hline
\end{tabular}

Based on table 3 based on the normality test data using "Shapiro Wilk" with the results showed that the data is not distributed normally, so to know the difference in knowledge before and after health education is used is an alternative test (Wilcoxon Test).

\section{b. Wilcoxon Test}

Table 4. The Effect of Health Education on Pregnant Women's Knowledge Level about COVID-19 at Cideng Medical Center Main Clinic Cirebon district in 2020

\begin{tabular}{ccccc}
\hline & & $\mathbf{N}$ & Median (Min-Max) & $\boldsymbol{P}$ \\
\hline Knowledge before & Negative Ranks & $0^{\mathrm{a}}$ & & \\
intervention $(\mathrm{n}=30)$ & Positive Ranks & $26^{\mathrm{b}}$ & $18(11-21)$ & 0,000 \\
Knowledge after & Ties & $4^{\mathrm{c}}$ & $20(19-21)$ & \\
intervention $(\mathrm{n}=30)$ & Total & 30 & & \\
\hline
\end{tabular}


Table 4 shows the results of Wilcoxon T Test in pretest and posttest pregnant women obtained a value of $\mathrm{p}$ value $=0.000$ or $p<0.05$ can be concluded that there is an influence of health education on the level of knowledge of pregnant women about COVID-19 at the Main Clinic Cideng Medical Center Cirebon District in 2020. Respondents with an increased knowledge score / positive rank as many as 26 people, settled / ties as many as 4 people and no respondents who decreased their knowledge/ negative ranks.

\section{Discussion}

\section{Characteristics of Respondents}

Knowledge is the result of human sensing, or the result of knowing a person to an object through his senses such as eyes, nose, ears and so on (Notoatmodjo, 2010a). Knowledge is influenced by several factors, namely age, education, economic status, environment, resources and social relations (Notoatmodjo, 2003). In this study, researchers only examined the characteristics of age and education respondents.

Age affects a person's level of knowledge. According to Notoatmodjo, age is very closely related to one's knowledge, because the more age the more the capture and mindset of a person. This means that age is one of the factors influencing information capture that ultimately affects increased knowledge, including knowledge about COVID-19.

Judging from the characteristics of respondents based on the age of most respondents aged 19 - 25 years as many as 13 people (43.3\%), where at that age respondents can be quite mature in receiving information that is new to him. This is in accordance with Aminingsih's research which states that the more mature the age, the more mature it will be, making it easier to receive information. The age of sufficient respondents will have a better level of knowledge (Aminingsih, Warsini, and Padmiati 2013). Astuti (2013) on The Characteristic Relationship of Pregnant Women With The Level of Knowledge About The Danger Signs In KePregnant In Sidoharjo Health Center Sragen District 
stated that there is a statistically meaningful relationship between the variable age with $\mathrm{p}$ value $=0.0001$.

Based on the level of education, most of the respondents of the education level is SMA / SMK which is 18 people $(60 \%)$, it shows that educated people are easier to receive new information or knowledge.

The level of education can determine the level of ability of a person in understanding and absorbing the knowledge that has been obtained. Education affects the learning process, the higher one's education, the easier it is for the person to receive information (Budiman 2014). According to Notoatmodjo, education can affect a person including one's behavior of lifestyle, especially in motivating to participate in development, in general the higher one's education the more receptive one is to receive information.

This is in accordance with the theory that the level of education pursued by individuals is one of the factors that will support his ability to receive information, as written by Utami (2007) that the higher the level of education of a person, the wider the way of view and way of thinking in the face of a situation that occurs around him.

2. Average Knowledge of Pregnant Women About COVID-19 Before and After Health Education at Cideng Medical Center Main Clinic Cirebon regency

Based on table 3 , the results showed that there is a significant difference between the level of knowledge of pregnant women before and after being given health education through video media about COVID-19. This shows the delivery of information about COVID-19 with health education through video media can change the knowledge of pregnant women at the Main Clinic Cideng Medical Center Cirebon Regency.

The results also showed the average value of knowledge during pretest at is 18.10 with a median value of 18 , a minimum value of 11 , a maximum value of 21 and a standard deviation of 1,749 after health education through video media (post-test) obtained an average value of 20.27 with a median value of 20 , a minimum value of 19 , a maximum value of 21 and a standard deviation of 0.785 . It is assumed that the information provided is conveyed 
well to respondents, resulting in an increase in the value of respondents' knowledge about COVID-19 after being given health education with a video about COVID-19 of 2.13.

Health education by using video media can increase pregnant women's knowledge about COVID-19 because the media used can attract respondents' attention by displaying real images and sounds from COVID-19 material. In addition, the health education material shown in the video is also easy to understand because it is directly at the core of the discussion and uses words that are easy to understand. The use of video media in health education causes respondents to absorb more knowledge because it involves the two largest senses in the absorption of information, namely the sense of vision and hearing (Ashyar, 2011).

This is in line with the results of research conducted by Zakaria (2017) conducted on pregnant women at the Jetis Health Center Yogyakarta which shows that there is an influence of health education with audiovisual media on the level of knowledge and attitude of pregnant women about the initiation of early breastfeeding.
This is in accordance with the theory that health education aims to change unhealthy behaviors into healthy which means that it can change the knowledge of respondents who are not good (Fitriani, Shinta, 2011). In addition, the results in this study are also supported by the theory that the selection and use of media aids is one of the important components carried out, with the aim of helping the use of the senses as much as possible (Ministry of Health, 2014). According to Ardianto (2013) in his research that changes in knowledge and attitudes or behavior changes are one of them influenced by the media in counseling. The existence of media in the counseling can affect knowledge, attitudes that can further affect the prevention of COVID-19 itself.

\section{The Effect of Health Education on} COVID-19 on Pregnant Women's Knowledge Level at Cideng Medical Center Main Clinic cirebon regency

Based on the results of the analysis conducted using wilcoxon $\mathrm{T}$ Test in table 6 obtained $p$ value of 0.000 , there is an influence of health education on the level of knowledge of 
pregnant women about COVID-19. The results of this study are in accordance with the results of the study of Chyntia Venty Ardiana, which states that health education interventions in mothers with video media have an effect on improving knowledge (Chyntia Venty Ardiana, 2016).

Knowledge is the result of human sensing, or the result of knowing a person's knowledge of objects through their senses such as eyes, nose, ears and so on. By itself at the time of sensing until it produces such knowledge is strongly influenced by the intensity of attention and perception of objects (Notoatmodjo 2010a).

The knowledge measured in this study is the knowledge of pregnant women which includes understanding, signs and symptoms, risk factors, ways of transmission and prevention of COVID-19.

Pregnant women's knowledge about COVID-19 is the result of knowing pregnant women about a specific condition of pregnancy where pregnant women are at risk of covid-19 infection. Knowledge will affect the mindset so that it can affect the behavior of pregnant women. Pregnancy is a normal, natural process that begins with the growth and development of intrauterine fetuses and begins from conception to childbirth (Dewi \&Sunarsih, 2011). Pregnancy causes various changes to the body and immune system (WHO, 2020). Corona virus or SARS-CoV-2 is a virus that attacks the respiratory system. Corona virus infection is characterized by several symptoms, such as fever, cough, and shortness of breath. In severe conditions, this viral infection can cause acute respiratory failure, severe pneumonia (pulmonary infection), pulmonary edema,malfunction of the organs, to death. Changes in the immune system that occur in pregnancy can make pregnant women more susceptible to coronavirus infection (POGI (Indonesian Society of Obstetrics and Gynaecology) 2020).

Data published by the Centers for Disease Control and Prevention (CDC) on Wednesday, September 16, 2020. This data contains two reports related to pregnancy and COVID-19. One of the reports contains data on 598 pregnant women affected by COVID-19 and hospitalized (Dwinanda, Reiny, 2020). The spread of coronavirus is increasing in Indonesia, pregnant women are becoming a group at risk of 
COVID-19 infection (WHO, 2020).

The lack of knowledge of pregnant women about COVID-19 can be one of the causes. Efforts can be made to provide information about COVID-19 through health education. The earlier health education about COVID-19 is provided, the lower the risk.

Bivariate test results using Wilcoxon T-Test obtained a value of $\mathrm{p}$ $=0.000$ or $\mathrm{p}<0.05$ means there is a significant difference between the level of knowledge of pregnant women before and after being given health education. This shows the delivery of information about COVID-19 with health education through video media can change the level of knowledge of pregnant women at the Main Clinic Cideng Medical Center Cirebon Regency.

Health education interventions will be conducted in this study with video media that include understanding, signs and symptoms, risk factors, ways of transmission and prevention about COVID-19.

Health knowledge can be improved by providing education about health through health education. Health education is one of the methods commonly used in health promotion whose emphasis is on changing or improving behavior through awareness raising, and efforts to maintain and improve health (Nur'azizaturrahmah, 2013).

Through health education, especially about COVID-19, respondents were given a new knowledge that they do not know so that pregnant women become affected in accordance with what researchers want, which is related to the habit of behaving clean and healthy life. In accordance with the stated by (Notoatmodjo, 2010b), that the provision of health education is an effort to create behaviors of pregnant women that are conducive to health. This means that here researchers provide stimulus in the form of new knowledge, most likely respondents feel the need to acquire that knowledge so that respondents respond that it is worth receiving. This is indicated by the respondent's knowledge score after being given health education improved than before being given health education. It is clear that health education here the level of knowledge and health of pregnant women is related 
to the habit of behaving clean and healthy life.

Health education cannot be released from the media because through the media, the messages delivered can be more interesting and understood, so that the target can study the message so that it decides to adopt positive behavior (Notoatmodjo 2010b)

The increase in knowledge is due to the learning process by the respondent and occurs due to the increase in sensitivity or readiness of the subject to the test given to the respondent. Knowledge is the result of knowing what happens after people have sensed a particular object. Sensing occurs through the senses of vision, hearing, smell and taste (Notoatmodjo, 2010a). Most of human knowledge is gained through the eyes and ears. Video media is one type of audio visual media. Audio visual media is a medium that relies on the sense of hearing and sense of vision (Ashyar, 2011).

Audio visual media (video) is the most appropriate tool today because the knowledge in a person is received through the senses reaches $75 \%$ to $87 \%$ of human knowledge obtained or channeled through the senses of view and $13 \%$ through the senses of hearing (Rahmawati, 2007).

Video media can channel knowledge to the brain more maximally because it provides a more tangible picture and can improve memory retention because it is interesting and memorable compared to other media (Maulana, 2009). According to (Kapti, $R$ 2013) audio visual media as a medium of effective health education is used to provide increased knowledge to mothers and change maternal attitudes for the better.

Sulastri (2016) in his research entitled The Influence of Health Counseling Using Video In Breast Examination Itself (SADAR) On Changes in Knowledge and Attitudes of Young Women in SMAN 9 Balikpapan Year 2012, showed the average value of respondents' knowledge before counseling was 18.44. While the average knowledge after counseling is 39.14 , with a $\mathrm{p}$ value of 0.000 or $\mathrm{p}<$ 0.05 means there is a significant difference in knowledge of respondents before and after health counseling activities using SADAR videos.

According to (Silva et al. 2017) stated there is an influence of health education on the level of knowledge of 
pregnant women. Farinta Isna Nur Fauziyyah research results, health education interventions using the media influence on maternal knowledge (Fauziyyah, Nur, and Andriani 2018).

Research conducted by (Kurniawati, 2012) with the title Differences In Media Leaflets and Videos on Maternal Knowledge on How to Overcome Complaints During Pregnancy, showed the results that there is a difference between media leaflets and videos to knowledge. The mean value in the video group (9.40) is higher than the leaflet group (5.80), so it can be concluded that the video media gives better results.

Post test is conducted after 1 day of health education. Hopefully there is no decrease in the memory of knowledge embedded in the respondent so that it can support the change of knowledge that is more inherent to the respondent (Rita L. Atkinson, 2000).

These results show that health education interventions conducted briefly will have a positive impact in improving one's knowledge (Fauziah, 2012). The results of this study are also in line with Maulana theory (2009) which states that information obtained from both formal and nonformal education can have an influence so as to produce changes or increase knowledge.

Based on the above research, it can be concluded that providing health education to pregnant women about COVID-19 with video media can increase the level of knowledge of pregnant women, so providing health education about COVID-19 is very important.

In terms of health education concept is all activities to provide or improve the knowledge, attitudes and practices of the community in maintaining and improving health (Notoadmodjo, 2003).

From this understanding, researchers or midwives here act as educators or givers of knowledge so that new knowledge is formed in pregnant women. Health education about COVID-19 with video media affects the level of knowledge in pregnant women. More attention is needed in the community about health education about COVID-19. Providing health education is prepared appropriately so that pregnant women easily understand and remember information and guided by the selection of adequate topics, 
methods, strategies, and media in an effort to increase knowledge and establish positive attitudes and behaviors.

\section{Conclusion}

Based on the results of research and discussion, it can be concluded that

1. The average increase in the knowledge level score of pregnant women between before and after being given health education was 2.13 .

2. There is an Influence of Health Education on The Level of Knowledge of Pregnant Women About COVID-19 at Cideng Medical Center Main Clinic in 2020 with the results of differences in pregnant women's knowledge about COVID-19 before and after the provision of health education about COVID-19 at Cideng Medical Center Main Clinic Cirebon district in 2020 .

\section{Suggestion}

Based on the conclusions of the research results that have been described, there are several things that are suggested as follows:
1. Main Clinic Cideng Medical Center Cirebon Regency

The results of this Health Education study are expected to still be applicable at Cideng Medical Center Main Clinic to be a guideline for midwives in providing Health Education to pregnant women about COVID-19 in order to increase the knowledge of pregnant women and midwives can provide health education videos about COVID-19 to pregnant women who come to Cideng Medical Center Main Clinic.

2. Other researchers

It is expected that this research can be used as a reference to conduct further research and can develop this research by increasing the number of samples so that the scope and generalization of research becomes wider and use different research methods or designs.

\section{Reference}

Aminingsih, S, Warsini, and Umi Padmiati. 2013. "Effect of Health Education on Knowledge And Skills In Breast Care In Post Psrtum Mothers In Oen Surakarta Hospital. KOSALA." JIK 1(2).

Ardianto. 2013. "Effect of Health Education with Audio Visual Method on HandWashing Behavior in Preschoolers in Aba Notoyudan 


\section{DOI: $\underline{10.34305 / g e m i c . v 1 i 1.314}$}

Kindergarten. Thesis."

Ashyar, Rayanda. 2011. Creatively Developing Learning Media. Jakarta: Gaung Persada (GP) Press.

Astuti, H. A. 2013. Asuhan Kebidanan Nifas Dan Menyusui. Jakarta: Erlangga.

Budiman, Riyanto A. 2014. Kapita Selekta Questionnaire of Knowledge and Attitudes In Health Research. Jakarta: Salemba Medika.

Fauziyyah, Farinta Isna Nur, and Kristien Andriani. 2018. "Effectiveness of Media Use To Improve Mother's Knowledge and Attitude About Breast Milk Companion Food (MP Asi) In Kenep Village, Sukoharjo Regency." Muhammadiyah University of Surakarta.

Kapti, R, E. 2013. "Audiovisual Effectiveness As a Medium of Health Abuse Against Increased Knowledge And Attitudes of Mothers In The Management of Toddlers With Diarrhea In Two Hospitals Malang." University of Indonesia.

Kurniawati, Nindya. 2012. "Differences Between Media Leaflets And Videos On Mother's Knowledge On How to Overcome Complaints During Pregnancy." http://garuda.ristekdikti.go.id.

Maulana, H. 2009. Health Promotion. Jakarta: EGC.

Notoatmodjo, Soekidjo. 2010a. Health Behavioral Sciences. Jakarta: PT. Rineka Cipta.

. 2010b. Health Promotion Theory and Application. Bloom F.E. Jakarta: PT. Rineka Cipta.

Nur'azizaturrahmah. 2013. "Differences in Knowledge Between Before And After Counseling Intervention Using Media Leaflet About The Causes of Dermatitis And Its Prevention In
Workers Finishing Wood Furniture In East Ciputat Year 2013." Health Sciences Syarif Hidayatullah State Islamic University Jakarta.

POGI (Indonesian Society of Obstetrics and Gynaecology). 2020. Recommendations for Handling Coronavirus Infection (COVID-19). Jakarta.

Pusicov Cirebon Regency. 2021. "COVID19 Data and Information Center. Covid Center Cirebon Regency. Quoted January 10, 2021." https://covid19.cirebonkab.go.id.

Pusicov Indonesia. 2021. "COVID-19 Data and Information Center. Covid Center Indonesia. Quoted January 10, 2021.” https://covid19.go.id.

Silva, Mônica Maria de Jesus, Denismar Alves Nogueira, Maria José Clapis, and Eliana Peres Rocha Carvalho Leite. 2017. "Anxiety in Pregnancy: Prevalence and Associated Factors." Journal of school of nursinguniversity of sao paulo 51(0): 1-8. http://www.scielo.br/scielo.php?script =sci_arttext\&pid=S0080-

$62342017000100444 \& \operatorname{lng}=e n \& \ln g=e$ n.

Simanjuntak, L. 2020. “Analysis of Anxiety Levels of COVID-19 and Factors Affecting Pregnant Women in Leo Simanjuntak SpOG's Doctor's Practice." Research, HKBP Nommensen University Medan. https://uhn.ac.id.

Sulastri. 2016. "Perawatan Hipertensi Dengan Labu Siam Terhadap Penurunan Tekanan Darah Hipertensi Pada Wanita Di Puskesmas Balongan Indramayu." Jurnal Care 4(3).

Utami, Pinilih Pangesti, Adi Isworo, Hanafi Moh, and Siti Arifah. 2017. "Jurnal Keperawatan Soedirman (The Soedirman Journal of Nursing), Volume 12, No.2 Juli 2017." Jurnal Keperawatan Soedirman (The 
Soedirman Journal of Nursing) 12(2): 77-83.

\section{journal:}

Aminingsih, S, Warsini and Padmiati Umi. (2013). Effect of Health Education on Knowledge And Skills In Breast Care In Post Psrtum Mothers In Oen Surakarta Hospital. KOSALA, JIK. Vol. 1 No.2, 2013.

Ardianto. (2013). Effect of Health Education with Audio Visual Method on HandWashing Behavior in Preschoolers in Aba Notoyudan

Kindergarten. Thesis. Yogyakarta : Faculty of Health Sciences.

Astuti, H. P. (2011). Characteristic Relationship of Pregnant Women with Knowledge Level of Danger Signs in Pregnancy in Sidoharjo Health Center, Sragen Regency. Kusuma Husada Health Journal, 3(2), 113. http://stikeskusumahusada.ac.id /jurnal/index.php/JK/article/view/4 $0 / 95$.

Kurniawati, Nindya. (2012). Differences Between Media Leaflets And Videos On Mother's Knowledge On How to Overcome Complaints During Pregnancy. Quoted July 14 , 2020 http://garuda.ristekdikti.go.id

L, Simanjuntak. (2020). Analysis of Anxiety Levels of COVID-19 and Factors Affecting Pregnant Women in Leo Simanjuntak SpOG's Doctor's Practice. Quoted May 8, 2020 https://uhn.ac.id. Research, $H$ KBP Nommensen University Medan.
Nur'azizaturrahmah. (2013). Differences in Knowledge Between Before And After Counseling Intervention Using Media Leaflet About The Causes of Dermatitis And Its Prevention In Workers Finishing Wood Furniture In East Ciputat Year 2013. Public Health Study Program Faculty of Medicine and Health Sciences Syarif Hidayatullah State Islamic University Jakarta, No3, c.30.

POGI. (2020). Recommendations for Handling Coronavirus Infection (COVID-19). Jakarta: Indonesian Society of Obstetrics and Gynaecology.

\section{Textbooks:}

Ashyar, Rayanda. (2011). Creatively Developing Learning Media. Jakarta: Gaung Persada (GP) Press Jakarta.

Budiman, Riyanto A. (2014). Kapita Selekta Questionnaire Of Knowledge and Attitudes In Health Research. Jakarta: Salemba Medika.

Maulana, H. (2009). Health Promotion. Jakarta:EGC.

Notoatmodjo, Soekidjo. (2010). Health Promotion Theory and Application. Jakarta: PT. Rineka Cipta. 17. Bloom F.E. 1988.

Notoatmodjo Soekidjo. (2010). Health Behavioral Sciences. Jakarta: PT Rineka Cipta.

\section{Thesis/Dissertation:}

Fauziyyah, Farinta Isna Nur and, Kristien Andriani, SKM, M.Si Kristien Andriani, SKM, M.Si (2018) Effectiveness of Media Use 
$1^{\text {st }}$ INTERNATIONAL SEMINAR OF GENDER, MATERNAL, EQUITY AND CHILD HEALTH

DOI: 10.34305/gemic.v1i1.314

To Improve Mother's Knowledge and Attitude About Breast Milk Companion Food (Mp Asi) In Kenep Village, Sukoharjo Regency. Thesis Thesis, Muhammadiyah University of Surakarta.

Kapti, R, E. (2013). Audiovisual Effectiveness As a Medium of Health Abuse Against Increased Knowledge And Attitudes of Mothers In The Management of Toddlers With Diarrhea In Two Hospitals Malang. Thesis Master Of Nursing Program, University of Indonesia Depok.
Website:

Pusicov Indonesia. (2021). COVID-19 Data and Information Center. Covid Center Indonesia. Quoted January 10, 2021 https://covid19.go.id

Pusicov Cirebon Regency. (2021). COVID-19 Data and Information Center. Covid Center Cirebon Regency. Quoted January 10 , 2021 https://covid19.cirebonkab.go.id 